Article

\title{
Landscape Design as a Tool to Reduce Soil Salinization: The Study Case of Keriya Oasis (NW China)
}

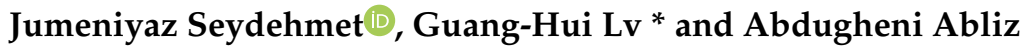 \\ Ministry of Education Key Laboratory of Oasis Ecology and College of Resources and Environmental Sciences, \\ Xinjiang University, Urumqi, Shengli Road 666, 830046 Xinjiang, China; jumeniyaz@xju.edu.cn (J.S.); \\ abdugheni.abliz@xju.edu.cn (A.A.) \\ * Correspondence: Ler@xju.edu.cn
}

Received: 14 March 2019; Accepted: 29 April 2019; Published: 5 May 2019

\begin{abstract}
Irrational use and management of water and land are associated with poor hydro-geological conditions causing water logging and salinization problems, possibly leading to farmland abandonment and economic loss. This poses a great challenge to the sustainability of oasis' and requires desalinization through reasonable landscape design by multiple crossing studies so we collected traditional knowledge by field interviews and literature schemes, except for the modern desalinization approaches by literature, and we found that the salinization problem has been solved by traditional land reclamation, traditional drainage, natural drainage and flood irrigation, locally. It is worth mentioning that the traditional reclamation in salinized areas requires flood water, sand dunes and a salinized pit area; the sand dunes are used to elevate the pit surface, and water is used to leach salt from the soil. Natural drainage (the depth and width are 4-10 m and 50-100 m, respectively) caused by flash flooding has significant benefits to some salinized villages in the range of 3000-5000 m and ancient groundwater drainage systems, such as Karez are supporting the oasis with drainage water for centuries. In addition landscape characteristics, salinization and hydro-geological conditions of the oasis were studied from Landsat image, DEM, literature and field photos. Then based on the gathered information above, a desalinization model was developed to decrease the groundwater table and salt leaching in the water logging landscape. Then according to landscape characteristics, different desalinization approaches were recommended for different landscapes. To address environmental uncertainties, an adaptive landscape management and refinement approach was developed, and acceptance of the model was validated by stakeholder opinion. The results provide guidelines for sustainable desalinization design and highlight the importance of combining traditional knowledge and modern ecological principles in sustainable landscape design.
\end{abstract}

Keywords: traditional knowledge; scientific knowledge; landscape ecology; adaptive management; interdisciplinary principle

\section{Introduction}

Interactive zones between irrigated farmland and the natural desert ecosystem, known as eco-tone areas, can develop secondary salinization as a result of irrational management of land and water resources with inherent flat geo-topological problems [1]. Under the complex interaction of anthropogenic and natural factors, salinization in the Keriya Oasis has shown a fluctuating trend, with salinized areas covering 1670 ha, 1554 ha and 1833 ha in 1991, 2002 and 2008, respectively [2-6]. In particular, farmland has been subjected to salinization and abandonment.

The Keriya Oasis has populated about 250,000 people, whose sustaining life mostly depend on agriculture: The main crops are wheat, maize, cotton, rice and grapes. Increasing socio-economic 
development has driven the farmland margin deep into the eco-tone frontier [5,7]. To meet the food demand of an increasing population in the future, more land will be converted to farmland, hence expanding the salinization risk. Currently, a lack of rational land and water management can cause excessive water logging in eco-tone areas (by groundwater seepage); meanwhile, other agricultural areas will experience an induced water shortage [8,9]. This demonstrates the great requirement of landscape designing to maximize the efficiency of land and water resource use and an opportunity exists to improve the eco-tone ecosystem (decrease the salinization threat) through ecological design and management $[10,11]$. It has been proven that the anthropogenic impacts on salinization can be positive [12]; therefore, artificial control of the salinization issue will be a key step towards sustainable social development in the oasis.

Ecological design approaches aim to restore human-impacted environments through natural processes by incorporating a wider consideration of traditional and scientific knowledge and encouraging the development of multifunctional sustainable landscapes that offer ecosystem services that promote social development [13]. Ecological design uses "human-nature dependency" and "cultural cohesiveness" to develop diverse, sustainable ecological design models on a case-by-case basis [14].The overall principles are to respect the landscape and traditional ecological knowledge and to be culturally sensitive by integrating bio-physical and socio-ecological inventories of the local environmental history $[13,15]$.

In addition, traditional ecological knowledge provides a pivotal source of inspiration to sustainable ecological design for today's eco-environmental problems [16,17], and it has recently been studied in the Three Gorges Reservoir shorelands. This type of comprehensive design increases the efficiency of water and land use [18-21]. When it comes to desalinization design in an arid oasis, there is a lack of diverse research in the area. Taking Keriya Oasis as an example, most studies in the area have concentrated on landscape monitoring and dynamics using RS technology, salinization assessment and mapping by using comprehensive traditional and scientific knowledge as well as other biophysical and socio-ecological factors. However, desalinization design on the landscape scale has rarely been investigated [5,7-9,22-26]. Globally, some scholars have used scientific methods to study salt leaching and drainage issues, while some others have studied traditional drainage systems, such as Karez, which bring sustainable economic benefits to local people in arid areas [27-29].

Therefore, our proposal combines the traditional and modern knowledge to investigate the desalinization methods, landscape, topography and hydrological conditions in Keriya Oasis. The aim of this study is the design of an optimized, ecologically sound and culturally desirable landscape desalinization management plan for the oasis.

\section{Methodology}

\subsection{Study Area}

The Keriya River basin, located in northwest China, is part of the county of Xinjiang Uyghur autonomous region [26] (Figure 1). The oasis is surrounded by a wide eco-tone area, which refers to the belt area located between the oasis and the neighboring desert (Figure 1). This is an interactive area between irrigated farmland and the desert ecosystem [1]. The basin is characterized by a warm dry climate with an annual temperature, precipitation and potential evaporation of $11.7^{\circ} \mathrm{C}, 45 \mathrm{~mm}$ and $2500 \mathrm{~mm}$, respectively. The area has an intrinsic salinization threat due to its relatively flat topography, loose sandy soil, high mineralized underground water, high salt concentrations on the soil surface and in groundwater and lack of soil fertility [23]. The people, whose employment and income mostly depend on agriculture, which depends on water resources from the Keriya River and the plain water reservoir of seepage water. The river is supplied by 430 glaciers in the mountains [30], and it disappears around the Derya Boyi village (Figure 1) after approximately $700 \mathrm{~km}$ of flow [7]. The basin has experienced aridity in some areas and secondary soil salinization elsewhere. 


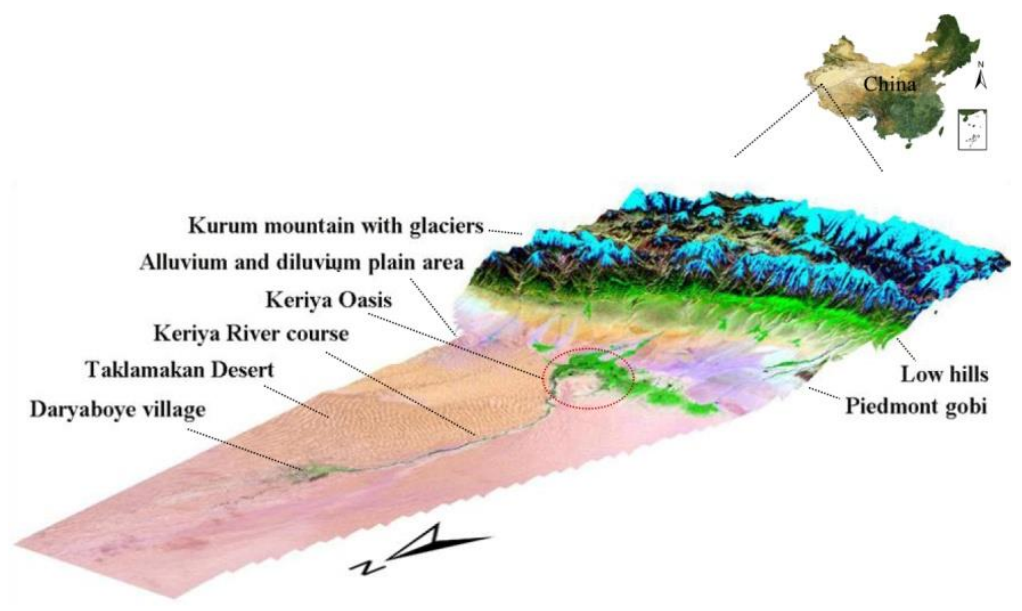

Figure 1. The location and topography of the study area.

\subsection{Methods}

The secondary soil salinization is a very complex problem [8,13-15,31,32]. Firstly, in order to make clear the mechanism of salinity hazards [8,9], this study built the socio-ecological and bio-physical conceptual models (Supplementary Materials) in the DPSIR frame [33] by a selected 39 variables $[7,8,10,18,19,31,34-36]$. Secondly, collected spatial and cross sectional hydro-geological data from various sources, and based on the built hydrological baseline map (Figure 7) to desalinization design. Thirdly, we determined the desalinization tool such as the drainage system through studying literature and from stakeholders' opinions, and to determine the desalinization plan for the landscape. Fourth, we test the plan by stakeholders' opinions and attitudes towards the design, and for the environmental uncertainties, the adaptive desalinization strategy was suggested. Details about data collection are as follows.

\subsubsection{Spatial Hydro-Geological Map}

To produce this mapin ArcGIS10.1, theLandsat-8 ETM+, GTOP30/DEM (resolution $30 \mathrm{~m}$, cloud $0 \%$, download date:21 July 2015) [37] were used for determine the thematic map of drainage, water bodies, river, farmland, basic landscape, contours, etc. [8,9],then the thematic map of salinization risk spatial distribution was produced from Seydehmet's study [9],finally, fold above together form the spatial hydro-geological map. The groundwater depth of 24 groundwater observation wells (sampling range of about 4-8 km, drilled in April 2012) were measured by using a HOBO barometric sensor. Then using datasets for the period of May 2012 to May 2013 we analyzed the spatial variation of the groundwater depth by ordinary kriging (subject to normal distribution, sig. is 0.55 ).

\subsubsection{Cross Section of Hydro-Geological Model}

A conceptual schematic cross section of the hydro-geological model was developed to provide guidelines to the desalinization design in the Keriya Oasis by the following steps: First, based on LUCC (Land use/cover change) [2] and the digital elevation model (DEM), the landscape were separated into five types as mountain, Gobi, oasis, eco-tone and desert. Second, studied on the hydro-geological characteristics of each type (including data from the river, reservoirs, springs and farmland) from literatures as in Keriya records [38] combined with the field observation and landscape photos, then determined the main dominant hydrological features as ET or infiltration. Third, according to stakeholders' opinions, field observation and photos, the farmland was divided into three types as farmland A, farmland B and farmland C, then based on the reference of the groundwater depth and it's relevant salinization risk (e.g., fertile farmland, salinized areas, marsh land and desert areas) [11], groundwater depth of the observation well and the states of the neighbor landscape, the approximate groundwater depth was determined for the main landscape types. 


\subsubsection{Drainage System and Groundwater Balance Model}

According to innovation time and structure, the drainage system including the modern and traditional system, in general. Recent decades, the modern drainage systems were developed in the farmland of Israel [27], are helpful for the design of desalinization, which is a system with shallow drainage (drain spacing of about $30 \mathrm{~m}$ ) and deep drainage (drain spacing range 60-120 m) combined with relief wells. Depending on the site conditions, there can be from three to 10 wells per hectare. The well diameters are usually $0.6 \mathrm{~m}$. The discharge of water from the wells into the deep drains reduces the upward flow of the groundwater towards the soil surface, consequently lowering the water level in the upper soil layers [27]. This model is suitable for use in the salinized farmland in the oasis.

There is also a historical innovation of drainage system as Karez (also termed the Foggara and the Qanat) is an ancient underground drainage system (Figure 2) that allowed water to drain to the surface using gravity to supply water for agriculture. This system has a long history of use and is widespread in western China, Iran, Arabia and the Mediterranean [29,39,40]. It has provided a pivotal source of inspiration for more sustainable ecological designs and management of today's environmental threats, and could be used for desalinization design in the oasis landscape.

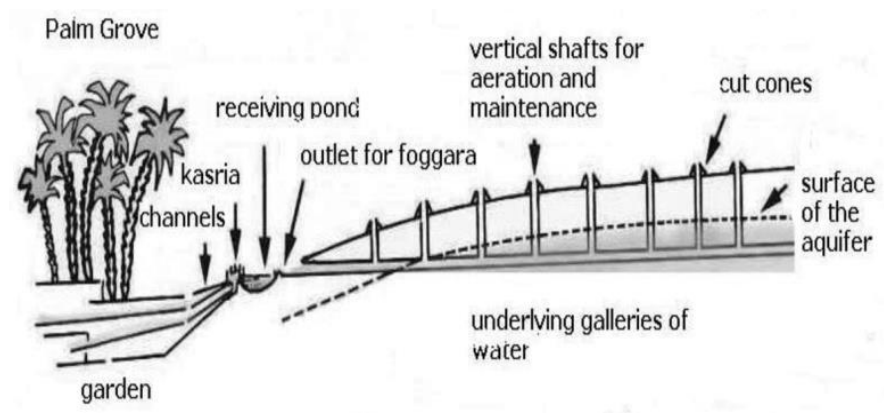

Figure 2. Karez profile [40].

The annual groundwater balance of the irrigated oasis can be estimated using the following equation [41]:

$$
W_{\Delta}=W_{\mathrm{r}}+W_{\mathrm{i}}+W_{\mathrm{c}}+W_{\mathrm{g} 1}-\left(W_{\mathrm{g} 2}+W_{\mathrm{d}}+W_{\mathrm{ex}}+W_{\mathrm{et}}\right)
$$

where $W_{\Delta}$ refers to the total existing groundwater of the oasis; $W_{\mathrm{r}}, W_{\mathrm{i}}, W_{\mathrm{c}}$ and $W_{\mathrm{g} 1}$ indicate the amount of water recharged by the rainfall, the irrigation, the canal leakage and the lateral groundwater inflow, respectively. $W_{\mathrm{g} 2}, W_{\mathrm{d}}, W_{\mathrm{ex}}$ and $W_{\mathrm{et}}$ refer to the amount of groundwater discharged through the groundwater outflow, the drains, the groundwater extraction and the evapotranspiration, respectively. This model provides a mathematical basis for decreasing groundwater by drainage in the desalinization design.

\subsubsection{Stakeholders' Opinions and Attitudes Towards the Design}

Stakeholders' opinions (traditional knowledge) and practices about land and water use were collected through field observations and semi-structured questionnaires during meetings [16]. A field survey was carried out in spring and autumn of 2012-2016. Figure 3 illustrates the method by which the survey on traditional knowledge was conducted. The main question, "What is Oasis's soil salinization desalinization approach?" was presented at a meeting, and then feedback questions were asked, followed by field verification. Through this, we tested our design ideas. After completion of the design draft, a second survey was performed. We presented participants with the desalinization conceptual model and asked about the acceptability of the desalinization model, and whether they would agree to manage and maintain aspects related to the design. This was assessed with a five-point scale (highly agree to disagree). 


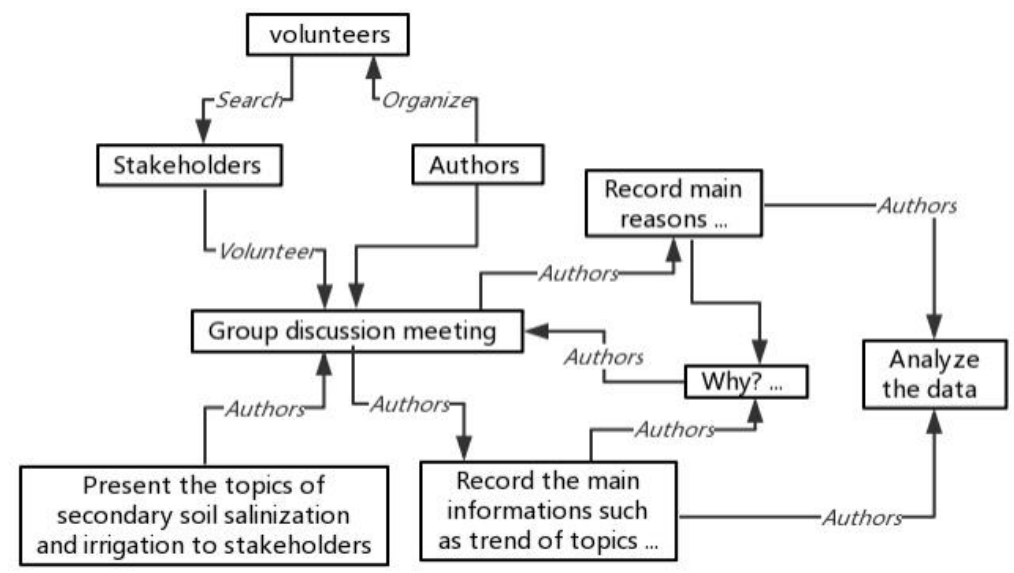

Figure 3. Diagram of the survey on traditional knowledge about the desalinization of secondary soil salinization.

\subsubsection{AdaptiveDesalinization Strategy}

There are many environmental uncertainties due to the scarcity of local data about desalinization. Therefore, it is necessary to develop adaptive management strategies. This is an iterative process of "trial and error" or "learning by doing", which progressively reduces uncertainty and achieves the desired function by continual system monitoring and adjustment [42,43]. According to the above principles, we addressed the environmental uncertainties in two phases, as shown in Figure 4.

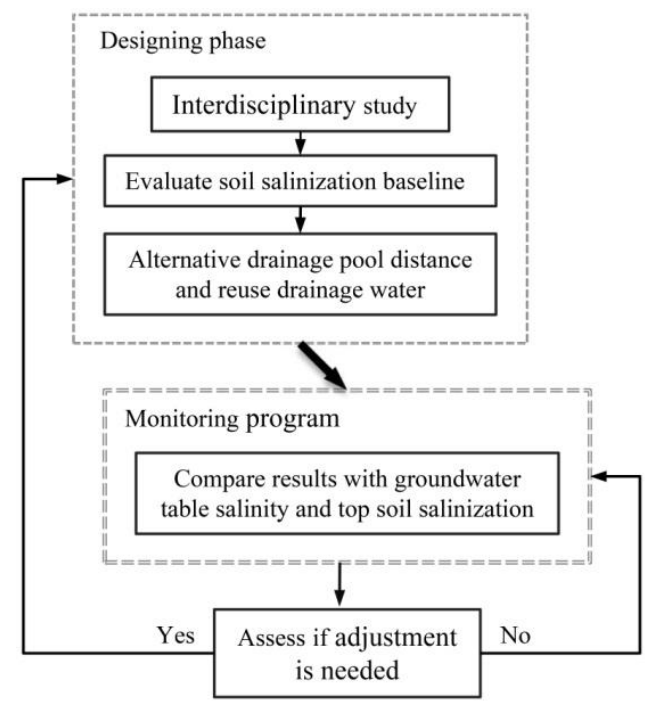

Figure 4. Adaptive landscape management for the desalinization of secondary soil salinization.

In the design phase, an interdisciplinary field investigation team of ecologists and stakeholders was set up for problem solving. For example, flash floods have created negative and positive impacts on the natural drainage, and their forms, the affected area range and the typical landscape characteristics of salinized farmland were verified by stakeholders during interviews. Photos of the Gobi desert were collected by field survey. In the maintenance phase, to increase the understanding of the groundwater table, salinity and surface salinity after implementation of the designed system, a monitoring program was performed, and refinement of the design system was necessary. 


\section{Results}

\subsection{Conceptual Scheme of the Hydro-Geological Model}

Due to the unique hydro-geological characteristics of the Keriya region (Figure 5), it slopes down from the south to the north through the mountains, the Gobi, the oasis, the eco-tone and the desert. Therefore, surface and groundwater typically flow from the south to the north (Figure 1). Slopes with loosesandy soil lead to the quick infiltration of surface water, and the seepage of groundwater is a common phenomenon in the area. Even in the Gobi area, a reservoir has formed from seepage water. The depth of the groundwater in the southern part of the oasis is bigger than $4 \mathrm{~m}$, causing drought, which affects crop growth.

Thedepth to the groundwater in the northern part of the oasis is less than $2 \mathrm{~m}$, causing a salinization threat to crops and a lack of salt leaching from irrigation water, which can even lead to land abandonment.

\subsection{Spatial Hydro-Geological Features}

Figures 6 and 7 clearly indicate that higher salinization stress was closely related to higher groundwater seepage intensity, a shallow groundwater table, low and flat terraces and poor drainage conditions. For example, the area between groundwater wells 17 and 24 was similar to the area of referenced landscape onthe contour map. These areas have some farmland, but there was less noticeable salinization hazard, due to the presence of a few tributaries of the Keriya River, which play a drainage function, as the seasonality of the Keriya River causes it to drain during the dry season. The roughly estimated distance to the drainage area was $5 \mathrm{~km}$ in all directions, which closely matches the stakeholders' suggestion. The northern part of the reference landscape had higher salinization stress than the south, because there was a lack of drainage and flat terraces. The majority of the farmland was distributed in the southeast part of the oasis, which featured higher slopes and was close to the Keriya River, where the drainage conditions were fine. 


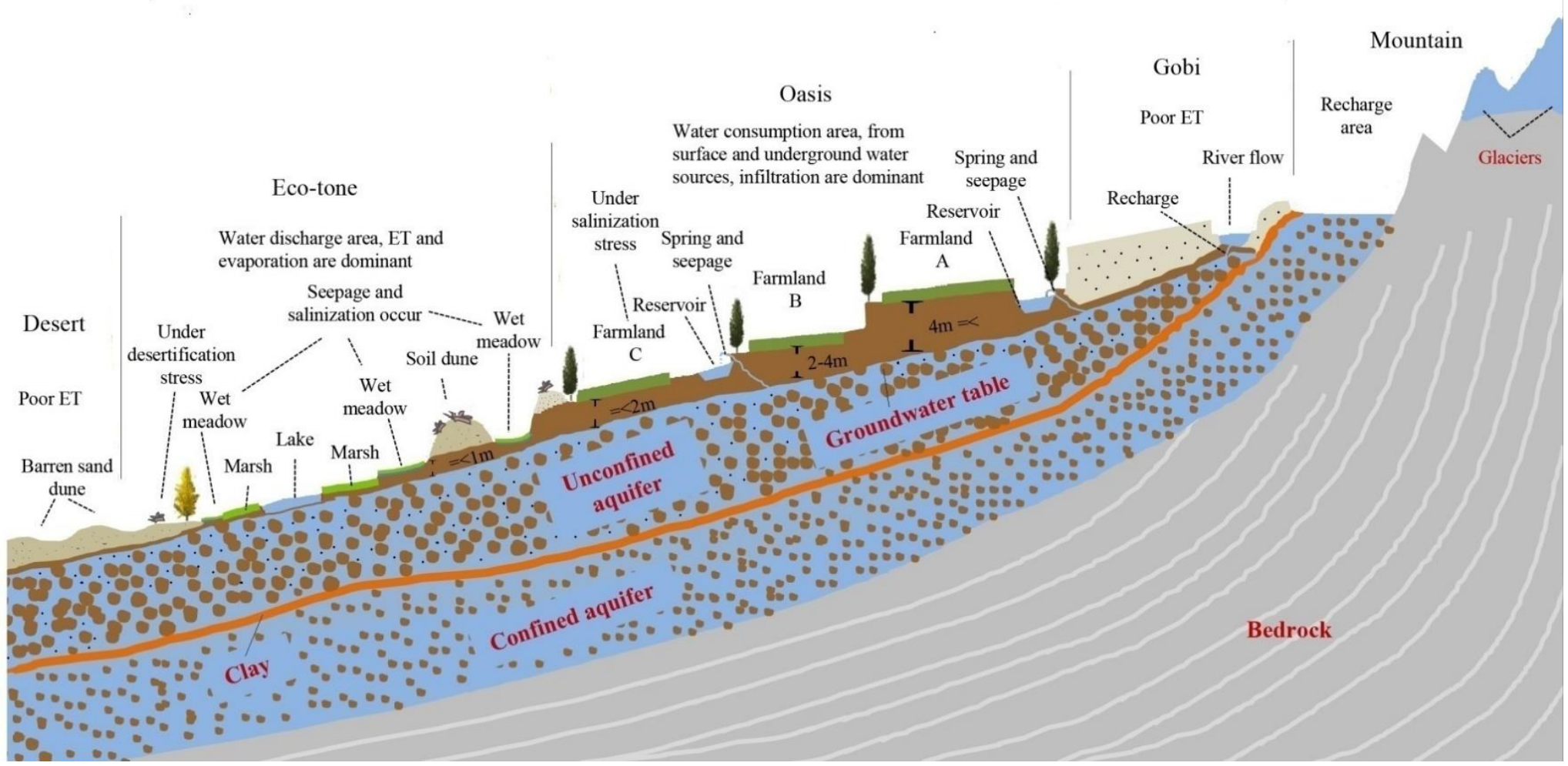

Figure 5. Conceptual schematic cross section of the hydro-geological model of the Keriya Oasis 


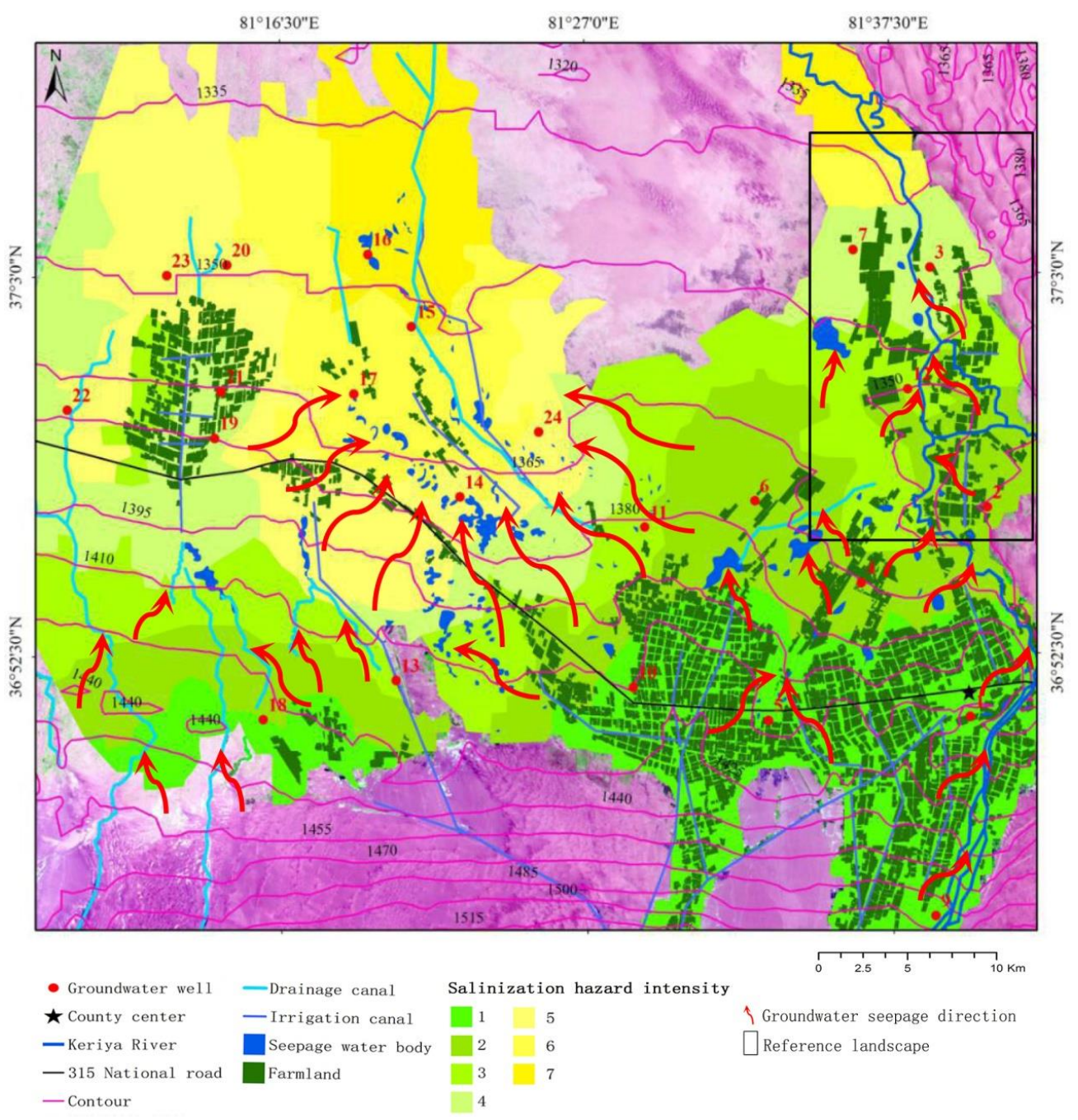

Figure 6. Spatial characteristics of the groundwater depth of the Keriya Oasis.

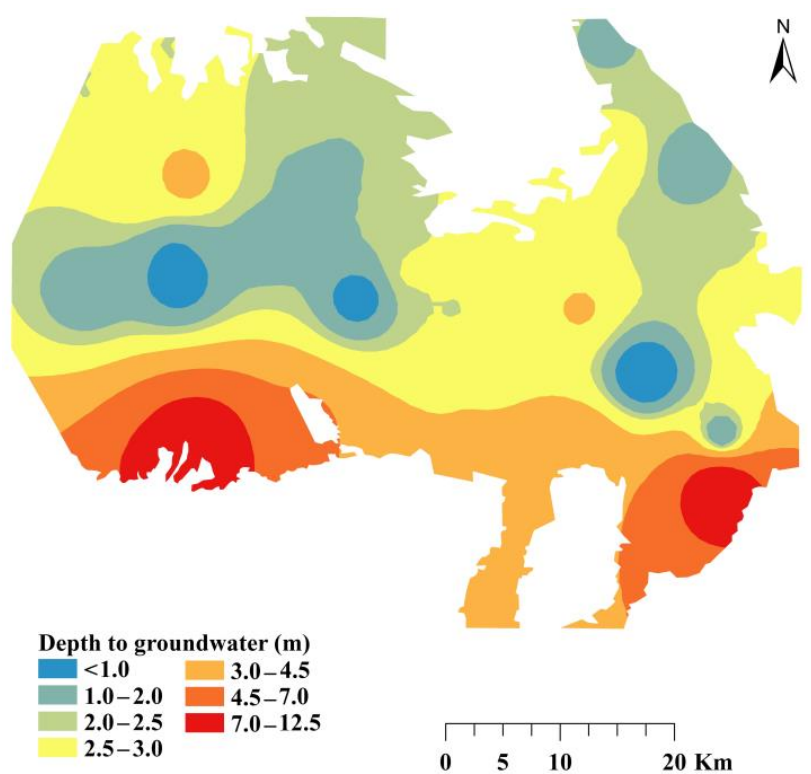

Figure 7. Spatial hydro-geological conditions of the Keriya Oasis, adapted from Seydehmet, J. [9]. Note: Higher numbers indicate higher salinization intensity. 


\subsection{Traditional Ecological Knowledge}

A total of 51 interviews each with six to ninelocal attendeeswere held, and 354 people were interviewed randomly around the Keriya Oasis. Interviewees were mainly men, who had traditionally been responsible for field work. Twenty-three percent were from the senior group, $56 \%$ were aged 40-60 yearsand $21 \%$ were younger than 40 years. Ninety-two percent had completed at least a primary education, and all of them had been residents of the Keriya Oasis for many generations.

From the interviews, we found that traditional land reclamation required sufficient floodwater, sand dunes and a pit area around the dunes. During this process, the sandy soil hillock was thrown into the water using hand tools, and then many sediments were relocated to the pit area, which changed the convex and concave surfaces to a plane surface that was ready for agriculture (Figure 8). This approach has two merits: First, it elevates the surface, and second, it leaches the salt from the soil, leading tohighly efficient desalinization or the prevention of salinization. Generally, the eco-tone area of the artificial oasis was reclaimed by this approach.

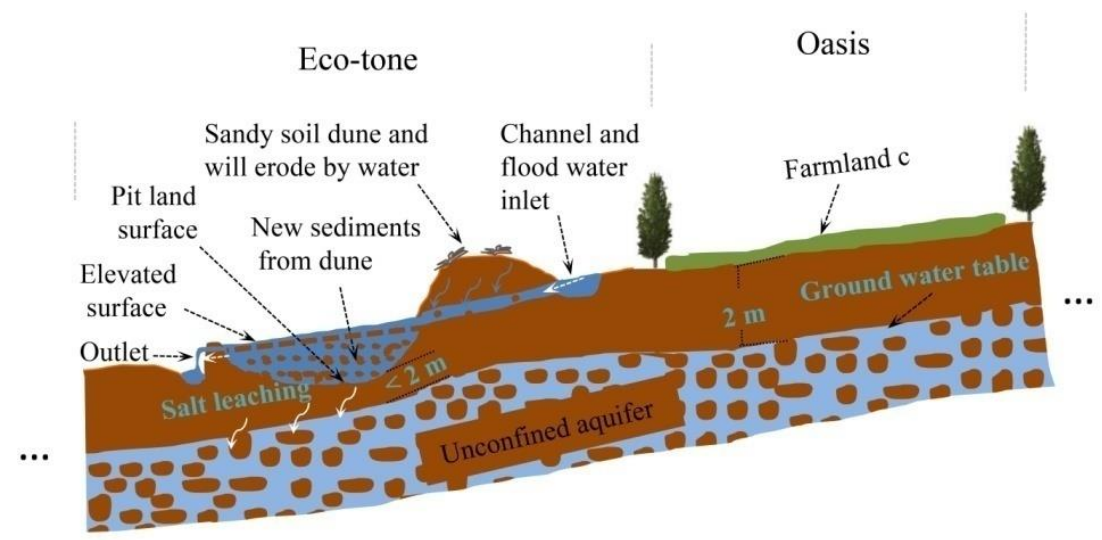

Figure 8. Conceptual schematic model of traditional land reclamation in the Keriya Oasis.

The local farmers preferred to use flood irrigation for the fields. According to stakeholders, the field was irrigated with $10-15 \mathrm{~cm}$ of water. The advantage of this method is that it leaches the salt from the fields, which have a shallow groundwater table but require regular irrigation. The field is relatively wet, but crop withers easily, and the field would become entirely dead by salinization if irrigation did not occur. Salinization hazard intensity level 4 (Figure 7) and farmland type c (Figure 5) are such types of farm.

A traditional drainage channel is dug by hand or machine and looks similar to a channel. Its main function is to decrease the groundwater table by allowing the effusion of ground water. Drainage channels are generally $2 \mathrm{~m}$ deep and $3 \mathrm{~m}$ wide, and a drainage system manages an area of 50-100 m around it at maximum. They are mostly used to prevent farmland salinization.

Natural drainage (termed drainage canalin Figure 7) caused by flash flooding (termed "Sel" in local) usually occurs due to heavy rain in the mountains that isunexpected and fast-moving. Generally, it creates a natural drainage ditch in the Gobi area by eroding the earth surface. Meanwhile, it leads to bed elevation of the pit area by depositing mud sedimentation in the lower reaches of its path [8]. According to stakeholders, once a natural drainage system has been created, a few villages will benefit from it, particularly in the reference landscape and in the southwest part of the oasis area (Figure 7). Field observations indicate that the natural drainage system depth was $4-10 \mathrm{~m}$ and the width is $40-100 \mathrm{~m}$ with an impact over an area of $3000-5000 \mathrm{~m}$. As the land slope decreased, the range of influence narrowed. 


\subsection{Desalinization Design for the Water Logging Area}

In the Karez drainage system (Figure 2), the groundwater drains out to the surface by gravity, and the drained water is reused for agriculture. The principles of traditional reclamation of salinized land include the use of elevate surfaces and salt leaching by flood irrigation (Figure 8). The conceptual layout of the desalinization model in the water logging area was developed using the natural drainage condition as a reference (Figure 9). The model of the groundwater budget (Equation 1) shows that the design layout is a logical way to decrease the groundwater table. The natural priorities were fully considered, such as the conservation of water bodies for local aesthetics and micro-climate humidity. Socio-ecological development needs were also considered, such as increasing the efficiency and sustainability of land and water resource use.

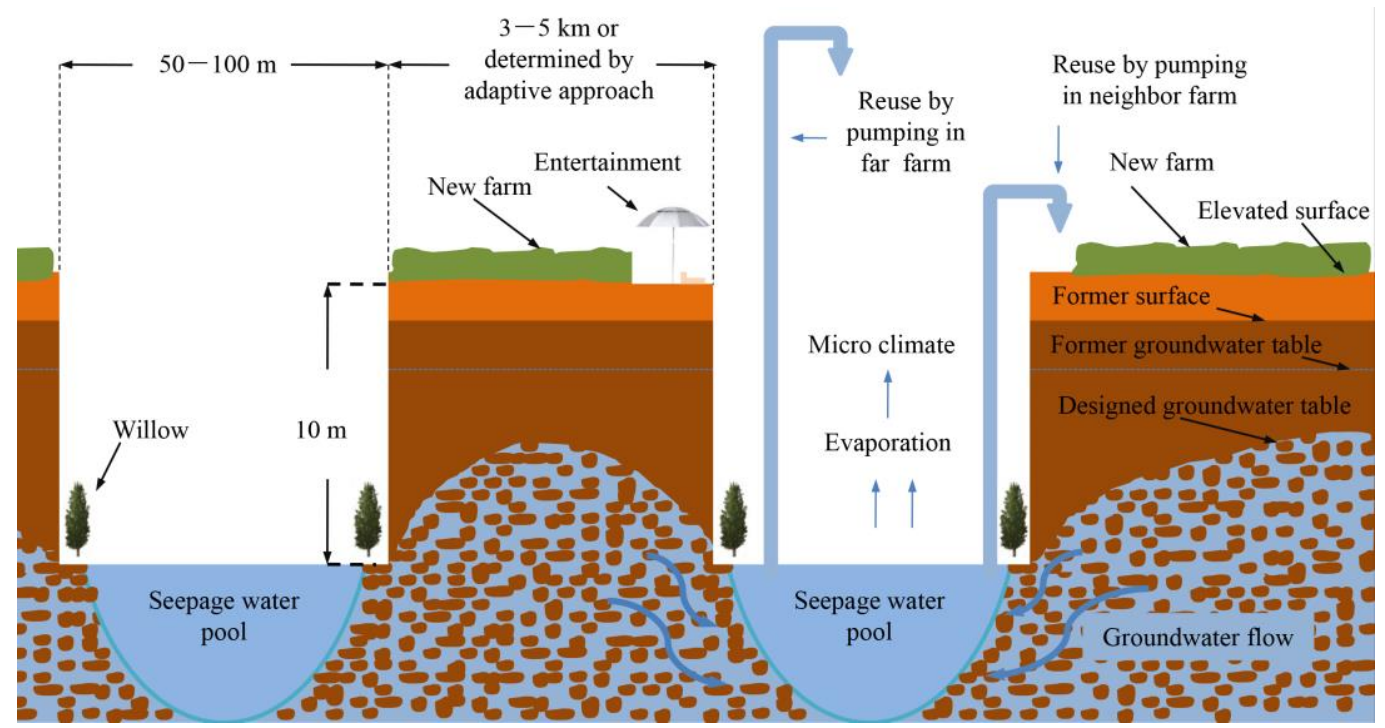

Figure 9. The cross section conceptual model of desalinization in the water logging area of the Keriya Oasis.

The spatial distribution of the layout is shown in Figure 10, where the spacing between seepage water pools (model of desalinization) was roughly $5 \mathrm{~km}$. Using adaptive landscape management (Figure 4), the groundwaterdepth (from groundwater observation wells) and surface salinity conditions should be monitored to decide the form of the next seepage pool and the direction of water reuse. If the surface is dry enough for irrigated agriculture, then the water can be reused by the neighboring farm; if not, it is transferred to a distant farm area that has been newly clamed from the desert.

A total of 109 stakeholders were visited in the second round of surveys, and we presented the design and its benefits to them (Figure 11). Overall, $24 \%$ of the stakeholders completely supported the desalinization conceptual model, and $42 \%$ of them agreed with the design. Overall, $64 \%$ of stakeholders agreed with the design, while $17 \%$ disagreed with it. Some stakeholders commented that they would like to accept this design, but they were afraid of the economic impacts. However, others stated that if the design plan gains official support, then there was no problem with it. The $14 \%$ of participants with a neutral option were those with no interest in the ecological design. 


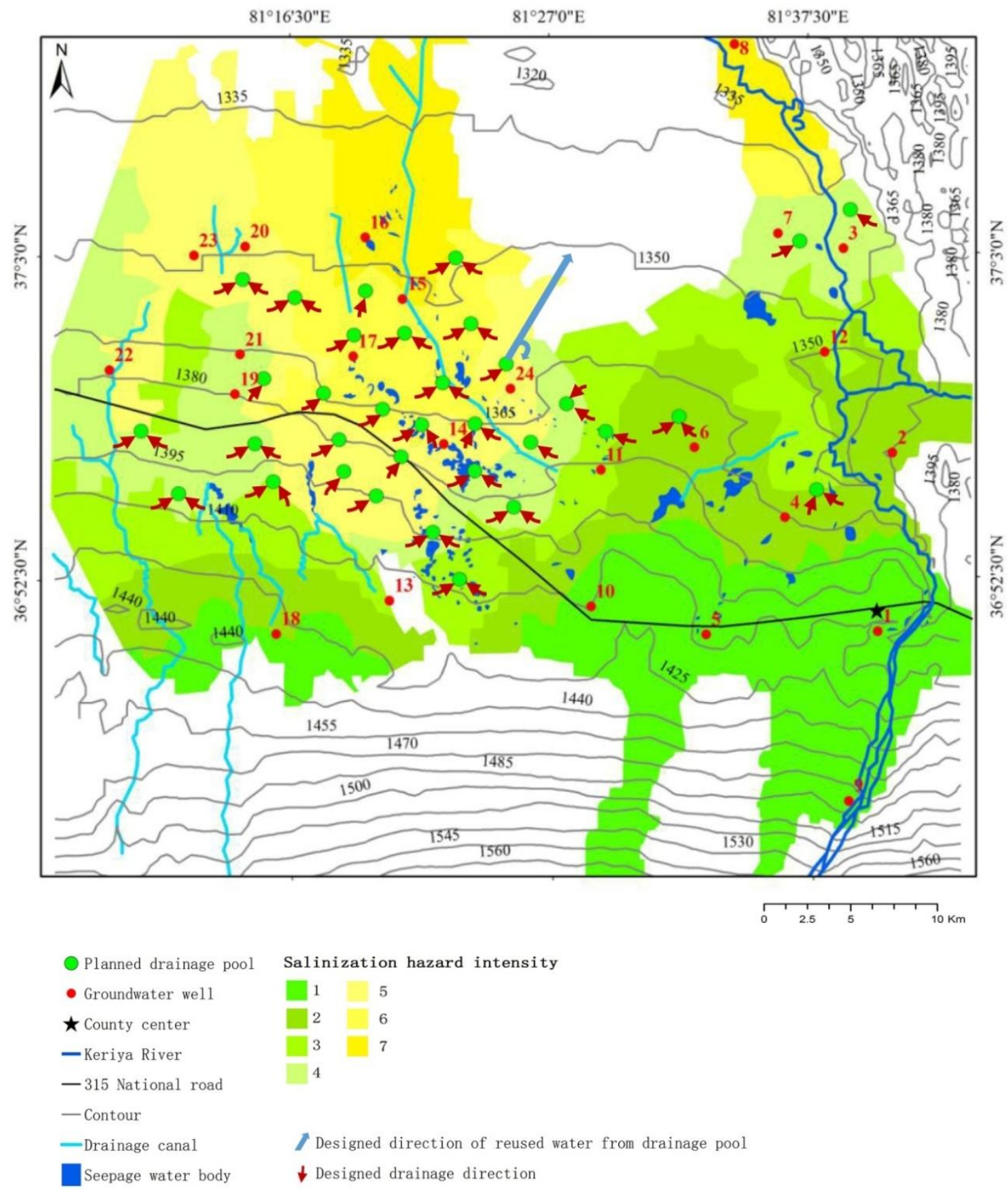

Figure 10. The spatial distribution of the conceptual layout of desalinization for the water logging area in the Keriya Oasis, adapted from Seydehmet, J. [9]. Higher numbers indicate higher salinization intensity. 


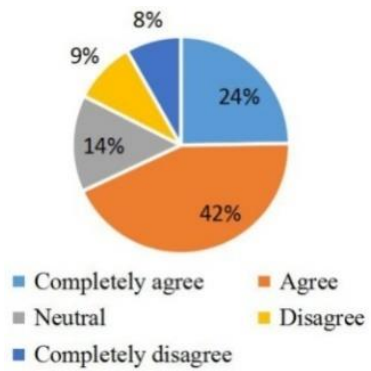

Figure 11. Attitudes towards the desalinization design.

\subsection{Landscape Management for Desalinization}

Different management strategies are recommended for different landscape futures, as shown in Table 1. Popoluseuphratica (termed Tugai forest) is a protected species in China [44], which must be considered. The marginal eco-tone area by the desert, being a frontier, has the important function of preventing the invasion of the desert into the oasis. Hence, it must be protected.

Table 1. Summary of typical landscape management strategy in the Keriya Oasis.

\begin{tabular}{|c|c|c|c|}
\hline $\begin{array}{l}\text { Type and } \\
\text { Symbols in } \\
\text { Figure } 6\end{array}$ & $\begin{array}{l}\text { Location and } \\
\text { Geo-Hydrological } \\
\text { Characteristics }\end{array}$ & Management Strategy & Illustration \\
\hline $\begin{array}{c}\text { Farmland }(a, b) \\
1\end{array}$ & $\begin{array}{l}\text { Groundwater table is } \\
\text { suitable, infiltration is } \\
\text { dominant, uses flood } \\
\text { irrigation, water use } \\
\text { efficiency is low. }\end{array}$ & $\begin{array}{l}\text { To decrease infiltration and increase the } \\
\text { irrigation efficiency, it is necessary to use } \\
\text { drip irrigation technology. }\end{array}$ & \\
\hline $\begin{array}{r}\text { Gobi } \\
2\end{array}$ & $\begin{array}{l}\text { Depth of ground water is } \\
\text { greater than } 4 \mathrm{~m} \text {, slope is } \\
\text { high, has good potential } \\
\text { drainage conditions. }\end{array}$ & $\begin{array}{l}\text { Could be used for future reclamation, but } \\
\text { would cause the groundwater table to rise } \\
\text { in farmland }(a, b, c) \text {. Hence, drainage should } \\
\text { bea priority. }\end{array}$ & \\
\hline $\begin{array}{c}\text { Farmland c } \\
3\end{array}$ & $\begin{array}{l}\text { Depth of ground water is } \\
\text { less than } 2 \mathrm{~m} \text {, flat terrace, } \\
\text { marginal farmland under } \\
\text { salinity hazard. }\end{array}$ & $\begin{array}{l}\text { Decrease the groundwater table and salt } \\
\text { leaching by modern or traditional drainage } \\
\text { with flood irrigation. }\end{array}$ & \\
\hline $\begin{array}{c}\text { Farmland c } \\
3\end{array}$ & $\begin{array}{l}\text { Depth of steady shallow } \\
\text { groundwater is less than } \\
2 \mathrm{~m} \text {, flat terrace, clay soil, } \\
\text { increasingly dry rice } \\
\text { field. }\end{array}$ & $\begin{array}{l}\text { Decrease the groundwater table, and } \\
\text { increase slopes and salt leaching using the } \\
\text { conceptual model of desalinization } \\
\text { presented in this study (Figure 9, Figure 10). }\end{array}$ & \\
\hline
\end{tabular}


Table 1. Cont.

\begin{tabular}{|c|c|c|c|}
\hline $\begin{array}{l}\text { Type and } \\
\text { Symbols in } \\
\text { Figure } 6\end{array}$ & $\begin{array}{l}\text { Location and } \\
\text { Geo-Hydrological } \\
\text { Characteristics }\end{array}$ & Management Strategy & Illustration \\
\hline $\begin{array}{l}\text { Wet meadow } \\
4\end{array}$ & $\begin{array}{l}\text { Depth of steady shallow } \\
\text { groundwater is less than } \\
2 \mathrm{~m} \text {, flat terrace, clay soil. }\end{array}$ & & • \\
\hline $\begin{array}{l}\text { Meadow and } \\
\text { farmland c } \\
4\end{array}$ & $\begin{array}{l}\text { Depth of steady shallow } \\
\text { groundwater is } 2 \mathrm{~m} \text {. } \\
\text { Under salinity stress. }\end{array}$ & & \\
\hline $\begin{array}{l}\text { Populuseuphratica } \\
\text { and meadow } \\
5\end{array}$ & $\begin{array}{l}\text { Depth of steady shallow } \\
\text { groundwater is more } \\
\text { than } 4 \mathrm{~m} \text {, located } \\
\text { northwest in the } \\
\text { marginal area of the } \\
\text { oasis and desert. }\end{array}$ & Preserved & \\
\hline $\begin{array}{c}\text { Inner marsh } \\
5\end{array}$ & $\begin{array}{l}\text { Depth of shallow } \\
\text { groundwater is less than } \\
1 \mathrm{~m} \text {, located in the inner } \\
\text { area of the oasis. }\end{array}$ & \multirow{4}{*}{$\begin{array}{l}\text { Decrease the groundwater table, and } \\
\text { increase the slopes and salt leaching using } \\
\text { the conceptual model of desalinization } \\
\text { presented in this study (Figure 9, Figure 10). }\end{array}$} & \\
\hline $\begin{array}{c}\text { Inner meadow } \\
6\end{array}$ & $\begin{array}{l}\text { Depth of shallow ground } \\
\text { water is less than } 2 \mathrm{~m} \text {, } \\
\text { located in the inner area } \\
\text { of the oasis. }\end{array}$ & & \\
\hline $\begin{array}{c}\text { Inner marsh } \\
6\end{array}$ & $\begin{array}{l}\text { Depth of shallow ground } \\
\text { water is less than } 1 \mathrm{~m} \text {, } \\
\text { located in the inner area } \\
\text { of oasis. }\end{array}$ & & \\
\hline $\begin{array}{c}\text { Inner marsh } \\
6\end{array}$ & $\begin{array}{l}\text { Depth of shallow } \\
\text { groundwater is less than } \\
1 \mathrm{~m} \text {, located in the inner } \\
\text { area of the oasis. }\end{array}$ & & \\
\hline $\begin{array}{c}\text { Marginal } \\
\text { meadow } \\
7\end{array}$ & $\begin{array}{l}\text { Depth of shallow } \\
\text { groundwater is less than } \\
2 \mathrm{~m} \text {, located in the } \\
\text { marginal area of the } \\
\text { eco-tone and desert. }\end{array}$ & Preserved & \\
\hline
\end{tabular}


Table 1. Cont.

\begin{tabular}{cll}
\hline $\begin{array}{c}\text { Type and } \\
\text { Symbols in } \\
\text { Figure } 6\end{array}$ & $\begin{array}{l}\text { Location and } \\
\text { Geo-Hydrological } \\
\text { Characteristics }\end{array}$ & Management Strategy \\
\hline $\begin{array}{c}\text { Marginal } \\
\text { meadow } \\
7\end{array}$ & $\begin{array}{l}\text { Depth of shallow } \\
\text { groundwater is greater } \\
\text { than 4m, located in the } \\
\text { marginal area of the } \\
\text { eco-tone and desert. }\end{array}$ & Preserved \\
\hline $\begin{array}{c}\text { Populuseuphratica } \\
\text { and meadow }\end{array}$ & $\begin{array}{l}\text { Depth of shallow } \\
\text { groundwater is greater } \\
\text { than 4m, located in the } \\
\text { marginal area of the } \\
\text { eco-tone and desert. }\end{array}$ & Preserved \\
\hline Margin marsh & $\begin{array}{l}\text { Depth of the shallow } \\
\text { groundwater is greater } \\
\text { than 4m, located in the } \\
\text { marginal area of the } \\
\text { eco-tone and desert. }\end{array}$ \\
\hline
\end{tabular}

\section{Discussion}

The dynamics of Keriya Oasis's landscape indicated that the oasis ecosystem was fragile, and it had experienced expansion and shrinking in slightly salinized areas. Excessive water logging at the eco-tone area had caused farmland salinization and even abandonment $[5,7,8,30]$.

The objective of this work was to design asustainable desalinization planning map. The methodology included the use of landscape ecology, a hydro-geological model, the modern drainage system, the concept of the traditional drainage system and adaptive management strategies. The idea of this work was to combine landscape ecological principles and traditional knowledge for ecological design in the arid oasis [5,7,22,45-52]. Our work suggests that traditional knowledge is the main intellectual source for modern sustainable ecological design.It is reported that, the groundwater table was significantly declined, for example, the Dunhuang oasis'sgroundwater table has been undergoing significant declined, owing to greater pumping, due to expanded irrigation and social-economic development [53]. This study highlights the respect to the nature, to decrease groundwater table, drained excessive groundwater by gravity and land slope, so there is less risk of groundwater table excessive decline.

Landscape ecology provides conceptual models and guidelines for sustainable ecological design. For instance, the intermediate disturbance hypothesis explains how proper anthropogenic or natural disturbance could increase biodiversity.In addition, during the design process, the following requirements should be satisfied: Sustainability, pertinancy, heterogenicity, diversity, economic efficiency, integrity and landscape individuality [42].These are the design principles and guidelinesfor desalinization design in low and flat salinized terrace areas of the Keriya Oasis.

Traditional knowledge of the environment and cultural values is valuable. For example, Karez, the specific concept of drainage groundwater and reuse greatly inspired this design idea, and traditional reclamation of salinized land can provide the salt leaching and prevent salinization, since it has adapted to the arid environment and supported anthropogenic activities and culture safely for over a thousand years. In addition, our design respects the local cultural aesthetics toward water bodies and the local micro-climate.

However, due to the scarcity of landscape design data related to desalinization in the oasis, our design may have some bias, although the map was validated by experts and stakeholders in the second round of interviews. The development of an empirical, comprehensive and quantitatively 
evaluated design is significant for this fragile landscape. Our spatiotemporal monitoring program will be supported by 24 groundwater observation wells [7], and it will evaluate the performance of the design and provide information for adjustments and extrapolation to other sites.

\section{Conclusions}

This landscape design was aimed at maximizing the efficiency of water and soil resources in a fragile arid ecosystem at a sustainable level. The design used a combination of traditional land-water management, landscape ecological principles, stakeholderengagement and modernecologicalapproaches in order to frame anecologically sustainable and culturally acceptable plan.Since, there were environmental uncertainties, we presented our desalinization design map to the community and receivedpositive feedback (validated by experts and stakeholders). We also suggested that the use of adaptive management strategies was indispensable when dealing with complex salinity problems. This study presented different desalinization approaches for different landscape, emphasizing that traditional knowledge is the main intellectual source for modern ecological design. The design map could be used as an exemplar forsustainabledesalinization in the arid oasis.

Supplementary Materials: The following are available online at http://www.mdpi.com/2071-1050/11/9/2578/s1.

Author Contributions: J.S. designed and wrote this paper, performed the experiments, and conducted the fieldwork; G.-H.L. conceived this study; A.A. was responsible for manuscript proofreading and data analysis.

Funding: This research was funded by the Natural Science Foundation of China, grant number 31560131and the Natural Science Foundations of China, grant number 41671348.

Conflicts of Interest: The authors declare no conflict of interest.

\section{References}

1. Wang, Y.; Li, Y. Land exploitation resulting in soil salinization in a desert-oasis ecotone. Catena 2013, 100, 50-56. [CrossRef]

2. Eziz, M.; Yimit, H.; Nijad, D.; Wei, B. The Response of Ecosystem Services Value to Land Use Change in Keriya Oasis, Northern Slope of Kunlun Mountain. Sci. Geogr. Sin. 2012, 32, 1148-1154. (In Chinese) [CrossRef]

3. Wiebe, B.H.; Eilers, R.G.; Eilers, W.D.; Brierley, J.A. Application of a risk indicator for assessing trends in dryland salinization risk on the Canadian Prairies. Can. J. Soil Sci. 2007, 87, 213-224. [CrossRef]

4. Zhou, D.; Lin, Z.; Liu, L.; Zimmermann, D. Assessing secondary soil salinization risk based on the PSR sustainability framework. J. Environ. Manag. 2013, 128, 642-654. [CrossRef]

5. Eziz, M.; Yimit, H.; Mohammad, A.; Zhifang, H. Oasis land-use change and its effects on the oasis eco-environment in Keriya Oasis, China. Int. J. Sustain. Dev. World Ecol. 2010, 17, 244-252. [CrossRef]

6. Kosmas, C.; Kairis, O.; Karavitis, C.; Ritsema, C.; Salvati, L.; Acikalin, S.; Alcalá, M.; Alfama, P.; Atlhopheng, J.; Barrera, J.; et al. Evaluation and Selection of Indicators for Land Degradation and Desertification Monitoring: Methodological Approach. Environ. Manag. 2013, 54, 951-970. [CrossRef] [PubMed]

7. Abliz, A.; Tiyip, T.; Ghulam, A.; Mamat, J.D.; Fei, S.; Ilyas, Z.; Abdugheni, N. Effects of shallow groundwater table and salinity on soil salt dynamics in the Keriya Oasis, Northwestern China. Environ. Earth Sci. 2016. [CrossRef]

8. Seydehmet, J.; Lv, G.H.; Nurmemet, I.; Aishan, T.; Abliz, A.; Sawut, M.; Abliz, A.; Eziz, M. Model Prediction of Secondary Soil Salinization in the Keriya Oasis, Northwest China. Sustainability 2018, 10, 656. [CrossRef]

9. Seydehmet, J.; Lv, G.H.; Abliz, A.; Shi, Q.D.; Turup, A. Irrigation Salinity Risk Assessment and Mapping in Arid Oasis, Northwest China. Water 2018, 10, 966. [CrossRef]

10. Mitsch, W.J.; Lu, J.; Yuan, X.; He, W.; Zhang, L. Optimizing ecosystem services in China. Science 2008, 322, 528. [CrossRef] [PubMed]

11. Fan, Z.L.; Ma, Y.-J.; Zhang, H.; Wang, R.H.; Zhao, Y.J. Research of eco-water table and rational depth of groundwater of Tarim River drainage basin. Arid Land Geogr. 2004, 27, 8-13. (In Chinese) [CrossRef]

12. Wang, G.Y.; Teyibai, T.; Tan, L.Z. Social Driven Forces to Land Use Variation in Yutian Oasis-desert Ecotone in Xinjiang. J. Desert Res. 2006, 26, 259-263. (In Chinese) [CrossRef] 
13. Chen, C.; Meurk, C.; Chen, J.; Lv, M.; Wen, Z. Restoration design for Three Gorges Reservoir shorelands, combining Chinese traditional agro-ecological knowledge with landscape ecological analysis. Ecol. Eng. 2014, 71, 584-597. [CrossRef]

14. Forman, R.T.T. Land Mosaics: The Ecology of Landscapes and Regions; Cambridge University Press: Cambridge, UK, 1995; p. 452.

15. Moshia, M.E.; Mashatola, M.B.; Shaker, P.; Fouche, P.S.; Boshomane, M.A.W. Land suitability assessment and precision farming prospects for irrigated maize-soybean intercropping in Syferkuil experimental farm using geospatial information technology. J. Agric. Soc. Res. 2008, 8, 138-147. [CrossRef]

16. Huntington, H.P. Using Traditional Ecological Knowledge in Science: Methods and Applications. Ecol. Appl. 2000, 10, 1270-1274. [CrossRef]

17. Berkes, F.; Colding, J.; Folke, C. Rediscovery of Traditional Ecological Knowledge as Adaptive Management Published by: Ecological Society of America rediscovery of traditional ecological knowledge. Ecol. Appl. 2010, 10, 1251-1262. [CrossRef]

18. Willison, J.H.M.; Li, R.; Yuan, X.Z. Conservation and eco-friendly utilization of wetlands associated with the Three Gorges Reservoir. Environ. Sci. Pollut. Res. 2013, 20, 6907-6916. [CrossRef]

19. Yuan, X.Z.; Zhang, Y.W.; Liu, H.; Xiong, S.; Li, B.; Deng, W. The littoral zone in the Three Gorges Reservoir, China: Challenges and opportunities. Environ. Sci. Pollut. Res. 2013, 20, 7092-7102. [CrossRef]

20. Li, B.; Xiao, H.; Yuan, X.; Willison, J.; Liu, H.; Chen, Z. Analysis of ecological and commercial benefits of a dike-pond project in the drawdown zone of theThree Gorges Reservoir. Ecol. Eng. 2013, 61, 1-11. [CrossRef]

21. Li, B.; Yuan, X.; Xiao, H.; Chen, Z. Design of the dike-pond system in the lit-toral zone of a tributary in the Three Gorges Reservoir, China. Ecol. Eng. 2011, 37, 1718-1725. [CrossRef]

22. Nurmemet, I.; Sagan, V. A WFS-SVM Model for Soil Salinity Mapping in Keriya Oasis, Northwestern China Using Polarimetric Decomposition and Fully PolSAR Data. Remote Seans. 2018. [CrossRef]

23. Gong, L.; Ran, Q.; He, G.; Tiyip, T. A soil quality assessment under different land use types in Keriya river basin, Southern Xinjiang, China. Soil Tillage Res. 2015, 146, 223-229. [CrossRef]

24. Mamat, Z.; Halik, U.; Muhtar, P.; Nurmamat, I. Influence of soil moisture and electrical conductivity on the growth of Phragmites australis (Cav.) in the Keriya oasis, China. Environ. Earth Sci. 2016, 75, 1-8. [CrossRef]

25. Hao, L.; Su, X.; Singh, V.P.; Zhang, L.; Zhang, G. Suitable oasis and cultivated land scales in arid regions based on ecological health. Ecol. Indic. 2019, 102, 33-42. [CrossRef]

26. Nurmemet, I.; Ghulam, A.; Tiyip, T.; Elkadiri, R.; Ding, J.L.; Maimaitiyiming, M.; Abliz, A.; Sawut, M.; Zhang, F.; Abliz, A.; et al. Monitoring soil salinization in Keriya River Basin, Northwestern China using passive reflective and active microwave remote sensing data. Remote Sens. 2015, 7, 8803-8829. [CrossRef]

27. Benyamini, Y.; Mirlas, V.; Marish, S.; Gottesman, M.; Fizik, E.; Agassi, M. A survey of soil salinity and groundwater level control systems in irrigated fields in the Jezre'el Valley, Israel. Agric. Water Manag. 2005, 76, 181-194. [CrossRef]

28. Corwin, D.L.; Rhoades, J.D.; Šimůnek, J. Leaching requirement for soil salinity control: Steady-state versus transient models. Agric. Water Manag. 2007, 90, 165-180. [CrossRef]

29. Hamidian, A.; Ghorbani, M.; Abdolshahnejad, M.; Abdolshahnejad, A. RETRACTED: Qanat, Traditional Eco-technology for Irrigation and Water Management. Agric. Agric. Sci. Procedia 2015, 4, 119-125. [CrossRef]

30. Ma, C.L.; Halik, W.; Liu, J.Q. The groundwater depth spatial temporal differentiation laws of different runoff changes in Keriya River Basin. J. Anhui Agric. Sci. 2013, 26. (In Chinese) [CrossRef]

31. Akramkhanov, A.; Martius, C.; Park, S.J.; Hendrickx, J.M.H. Environmental factors of spatial distribution of soil salinity on flat irrigated terrain. Geoderma 2011, 163, 55-62. [CrossRef]

32. Huang, J.; Prochazka, M.J.; Triantafilis, J. Irrigation salinity hazard assessment and risk mapping in the lower Macintyre Valley, Australia. Sci. Total Environ. 2016, 551-552, 460-473. [CrossRef] [PubMed]

33. Spangenberg, J.H.; Douguet, J.M.; Settele, J.; Heong, K.L. Escaping the lock-in of continuous insecticide spraying in rice: Developing an integrated ecological and socio-political DPSIR analysis. Ecol. Model. 2015, 295, 188-195. [CrossRef]

34. Hamzeh, S.; Naseri, A.A.; AlaviPanah, S.K.; Mojaradi, B.; Bartholomeus, H.M.; Clevers, J.G.P.W.; Behzad, M. Estimating salinity stress in sugarcane fields with spaceborne hyperspectral: Vegetation indices. Int. J. Appl. Earth Obs. Geoinf. 2012, 21, 282-290. [CrossRef]

35. Yao, R.; Yang, J. Quantitative evaluation of soil salinity and its spatial distribution using electromagnetic induction method. Agric. Water Manag. 2010, 97, 1961-1970. [CrossRef] 
36. Zhou, D.; Lin, Z.; Liu, L.; State, N.D.; Dakota, N. Developing a Composite Risk Index for Secondary Soil Salinization Based on the PSR Sustainability Framework. In Proceedings of the 6th International Congress on Environmental Modelling and Software, Leipzig, Germany, 1-5 July 2012.

37. U.S. Geological Survey. Available online: http://glovis.usgs.gov/ (accessed on 21 July 2015).

38. Wei, Y.L.; Wang, H.; Li, N. Keriya County Annals, 1st ed.; Xinjiang People's Press: Urumqi, Xinjiang, China, 2006; pp. 142-148, 162-164, 173-181, 300-313. (In Chinese)

39. Tursun, T.; Jialalidin, A.; Mamat, R. A study on the ancient Turpan Karez engineering technologyand measuring method. Geotech. Investig. Surv. 2014, 42, 63-67. [CrossRef]

40. Amine, M.; Bendida, A.; Khelfaoui, R. The impact of traditional irrigation (Foggara) and modern (drip, pivot) on the resource non-renewable groundwater in the Algerian Sahara. Energy Procedia 2013, 36, 154-162. [CrossRef]

41. Li, P.; Wu, J.; Qian, H. Regulation of secondary soil salinization in semi-arid regions: A simulation research in the Nanshantaizi area along the Silk Road, northwest China. Environ. Earth Sci. 2016, 75, 1-12. [CrossRef]

42. Xiao, D.N.; Li, X. Zh.; Gao, J. Landscape Ecology, 5th ed.; Science Press: Peijing, China, 2007; pp. 114-203. (In Chinese)

43. Nassauer, J.I.; Opdam, P. Design in science: Extending the landscape ecology paradigm. Landsc. Ecol. 2008, 23, 633-644. [CrossRef]

44. Wang, S.J.; Chen, B.H.; Li, H.Q. Populus euphratica Oliv, 1st ed.; China Environmental Science Press: Beijing, China, 1995. (In Chinese)

45. Wang, H.W.; Fan, Y.H.; Tiyip, T. The research of soil salinization human impact based on remote sensing classification in oasis irrigation area. Procedia Environ. Sci. 2011, 10, 2399-2405. [CrossRef]

46. Zhang, W.T.; Wu, H.Q.; Gu, H.B.; Feng, G.L.; Wang, Z.; Sheng, J.D. Variability of Soil Salinity at Multiple Spatio-Temporal Scales and the Related Driving Factors in the Oasis Areas of Xinjiang, China. Pedosphere 2014, 24, 753-762. [CrossRef]

47. Yu, P.; Xu, H.; Liu, S.; Qiao, M.; Zhang, Q.; An, H.; Fu, J. Spatial distribution pattern changes of oasis soil types in Manasi River Basin, arid northwestern China. Catena 2011, 87, 253-259. [CrossRef]

48. Xie, Y.; Gong, J.; Sun, P.; Gou, X. Oasis dynamics change and its influence on landscape pattern on Jinta oasis in arid China from 1963a to 2010a: Integration of multi-source satellite images. Int. J. Appl. Earth Obs. Geoinf. 2014, 33, 181-191. [CrossRef]

49. Muhtar, P.; Yimit, H. Ecosystem Services Sensitivity to Land-use Change:A Case Study of the Keriya Oasis. J. Nat. Resour. 2014, 29, 1849-1858.

50. Zhang, B.; Xiong, H.; Xu, C.C. Study on Ecological Resilience and Environment in Yutian Oasis, Xinjiang. Res. Soil Water Conserv. 2008, 15, 112-114.

51. Ling, H.; Xu, H.; Fu, J.; Fan, Z.; Xu, X. Suitable oasis scale in a typical continental river basin in an arid region of China: A case study of the Manas River Basin. Quat. Int. 2013, 286, 116-125. [CrossRef]

52. Amuti, T.; Luo, G. Analysis of land cover change and its driving forces in a desert oasis landscape of Xinjiang, northwest China. Solid Earth 2014, 5, 1071-1085. [CrossRef]

53. Zhang, X.; Zhang, L.; He, C.; Li, J.; Jiang, Y.; Ma, L. Quantifying the impacts of land use/land cover change on groundwater depletion in Northwestern China-A case study of the Dunhuang oasis. Agric. Water Manag. 2014, 146, 270-279. [CrossRef]

(C) 2019 by the authors. Licensee MDPI, Basel, Switzerland. This article is an open access article distributed under the terms and conditions of the Creative Commons Attribution (CC BY) license (http://creativecommons.org/licenses/by/4.0/). 